\title{
Estimation of usage efficiency of freon-steam turbines in mine energy complexes
}

\author{
Mykhailo Kirsanov ${ }^{1, *}$, Inna Diakun ${ }^{1}$, Vitalii Ruban ${ }^{1}$,Viktor Skosyriev ${ }^{2}$, and Oleksandr \\ Zhevzhyk $^{3}$ \\ ${ }^{1}$ Institute of Geotechnical Mechanics named by N. Poljakov of National Academy of Sciences of \\ Ukraine, 49005, Dnipro, Simferopolska Str., 2a, Ukraine \\ ${ }^{2}$ Pryazovskyi State Technical University, 87555, Mariupol, Universytetska Str., 7, Ukraine \\ ${ }^{3}$ Dnipro National University of Railway Transport named after Academician V. Lazaryan, 49010, \\ Dnipro, Lazaryan Str., 2, Ukraine
}

\begin{abstract}
Increase of operating efficiency of mine energy complexes is an actual scientific and technical problem. Systems that utilize energy of lowpotential sources and have freon-steam turbines are suggested to be included in mine energy complexes. Principles of selection of freons as working fluids in energy systems are suggested in the paper. Usage of some thermal equations of state for defining thermal and physical properties of freons is analyzed. Equation of isentropic process for the thermal Redlich-Kwong equation of state is obtained. Calculation of energy efficiency of a system with a freon-steam turbine for selected variants of usage of working fluids is performed. A calculation method of thermodynamic parameters that are necessary for energy conversion efficiency estimation of specific freons in a system of useful utilization of energy is developed. Analysis of results indicates that usage of ozone-safe and fire-safe freons in energy utilization systems of low-potential sources with a possibility of utilization of additional waste heat, which was not used in the past, allows increasing the operating efficiency of mine energy complexes.
\end{abstract}

\section{Introduction}

Requirements of the modern situation on economical use of non-renewable resources lead to a necessity of development of technical solutions aimed at the usage of waste heat sources of various origin. Large volumes of waste heat are produced during operation of main technological equipment of mine energy complexes (MEC) [1]. Geothermal energy and concentrated solar radiation are as interesting for useful utilization as waste heat of secondary (waste) energy resources (WER) of main technological equipment in mining, in particular, coal industry, and metallurgy. Temperature range of low-potential energy sources can be roughly estimated by the interval of $305 \mathrm{~K}\left(32^{\circ} \mathrm{C}\right)$ to $573 \mathrm{~K}\left(300^{\circ} \mathrm{C}\right)$. These temperatures characterize mine water in mining industry, water after cooling various aggregates, hot air after technological processes, and geothermal water in other industries

\footnotetext{
*Corresponding author: mvksvd1704@gmail.com
} 
[2-4]. The analysis of structure of such WER with the indicated temperature range shows that the common property is as follows: the lower the value of temperature (temperature potential) is, the larger volume (flow rate) of WER can be usefully utilized.

A large part of such WER is currently not utilized or are used as thermal energy for internal needs of enterprises, such as heating water for mine showers or heating production areas. Discharge of such WER into rivers and natural reservoirs contributes to water heating and disturbing the conditions of ecosystem vital functions. It should be noted, that utilization of thermal energy is changed seasonally and is drastically reduced during the warm time of year. One of the possible ways of utilizing the considered WER is conversion into electrical energy. This type of energy can be easily sold, accumulated, and used regardless of the time of year. A traditional method of such a conversion is usage of a steam turbine, in which heated water expands into the region of two-phase states. A series of research indicates that this method is applied for utilization of WER with a low temperature potential with a low energy conversion efficiency (ECE) [5]. Consider an expression for calculation of thermodynamic cycle ECE of a steam turbine [5]

$$
\eta=1-\frac{\ln \tau}{\tau-1}, \quad \tau=\frac{T_{2}}{T_{1}}
$$

where $T_{1}, T_{2}$ are temperatures of water cooling and heating, respectively, $\mathrm{K}$.

A calculation by formulas (1) indicates that for $T_{2}=383 \mathrm{~K}\left(110^{\circ} \mathrm{C}\right), T_{1}=293 \mathrm{~K}\left(20^{\circ} \mathrm{C}\right)$, a steam turbine cycle ECE is $12.8 \%$, and for $T_{2}=323 \mathrm{~K}\left(50^{\circ} \mathrm{C}\right), T_{1}=293 \mathrm{~K}\left(20^{\circ} \mathrm{C}\right) \mathrm{a}$ steam turbine cycle ECE is $4.8 \%$ (Fig. 1).

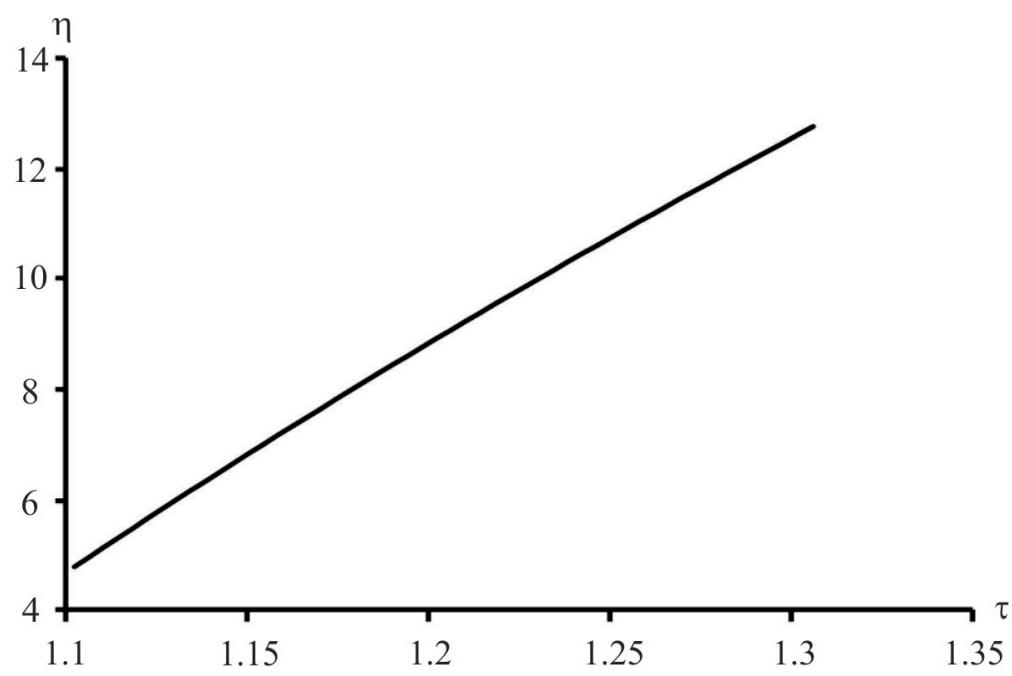

Fig. 1. Dependency of thermodynamic cycle ECE of steam turbine on $\tau$.

It is obvious that an industrial usage of technologies with ECE of less than $5 \%$ is inefficient. Results of analysis of possible ways of ECE increase of a conversion process of WER into electric energy indicate the necessity of inclusion of an energy utilization system of low-potential sources in MEC. These systems realize the Rankine thermodynamic cycle with usage of freon as a low-boiling working fluid. Considering the requirements of the Montreal Protocol on substances that deplete the ozone layer and fire safety at MEC, the most perspective working fluids are the freons of ozone-safe classes with $O D P=0$ (Ozone Depletion Potential) as low-boiling working fluids [6].

Experience of application of such fluids in cold-generating systems and heat pumps is 
well known [3, 6, 7]. Although, an experience of application in the conditions of MEC with a purpose of creating systems of utilizing low-potential heat is unknown to the authors.

Thus, the purpose of the paper is to estimate the efficiency of usage of freon-steam turbines in MEC for conversion of heat of waste sources with a temperature potential in the range of $305 \mathrm{~K}\left(32^{\circ} \mathrm{C}\right)$ to $333 \mathrm{~K}\left(60^{\circ} \mathrm{C}\right)$ into electric energy.

\section{Methods}

It is most rational to use the Rankine cycle (Fig. 2) when utilizing the energy of lowpotential sources with a low-boiling working fluid. The Rankine cycle assumes heating the working fluid in heat exchangers and a freon-steam generator, expansion in a turbine with an output of useful mechanical work to electric generator, and further freon condensation to a state of saturated liquid. A pump is used for closing the working fluid circulation in the Rankine cycle with a purpose of freon supply from a condenser to a heat exchanger.

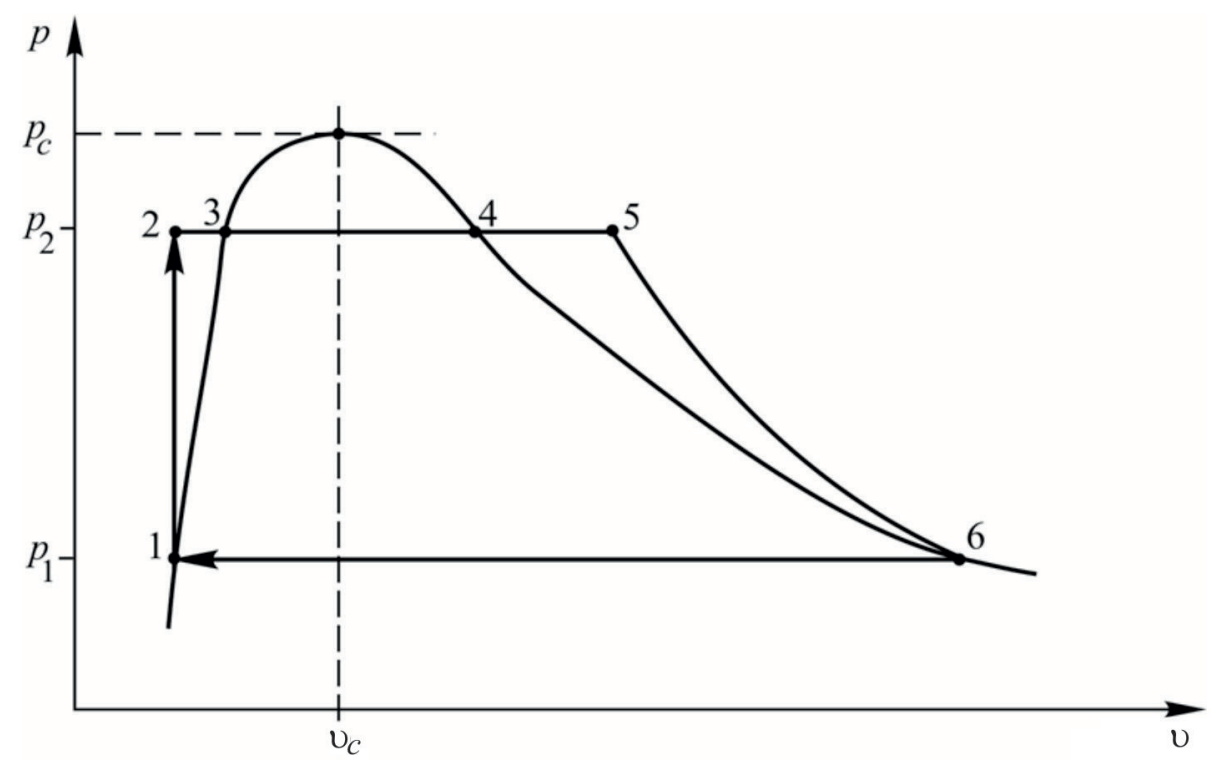

Fig. 2. Rankine cycle in coordinates "pressure $p$ - specific volume $v$ ", where $p_{1}, p_{2}$ are freon pressures on lines "2-5" and "6-1", $\mathrm{Pa} ; p_{c}, \mathrm{v}_{c}$ are pressure $(\mathrm{Pa})$ and specific volume $\left(\mathrm{m}^{3} / \mathrm{kg}\right)$ at critical point, respectively.

As seen in Figure 2, working fluid state change along line "6-1" corresponds to condensation of freon steam to a state of saturated liquid at point "1", and movement along line "1-2" corresponds to freon supply to a heat exchanger by a pump. Freon is sequentially heated on line "2-3-4" until evaporation at point " 3 " and is converted into a state of dry saturated steam at point "4". Superheating of freon steam occurs in freon steam super heater - point "5". Working fluid movement along line "5-6" corresponds to steam operation in a freon-steam turbomachine. Heat supply from a low-potential source to freon occurs along the entire line "2-5". Heat is not supplied to a working fluid along line "5-6". The region located under line "1-3- $p_{c}-4-6$ " in Figure 2 corresponds to two-phase (steamliquid to be exact) state of freon. Relative location of lines "5-6" and "4-6" in the Rankine cycle for freons substantially depends on its thermodynamic properties.

An estimation of thermodynamic efficiency of freon usage is performed in this paper through calculation of thermodynamic ECE of the Rankine cycle. The ECE is determined 
by a ratio of mechanical work, which is numerically equal to the area of a figure formed by lines "1-2-3-4-5-6-1" of the cycle, to heat amount, which working fluid supplies to cooling environment in a condenser on line "6-1". Freon temperature on line "6-1" is constant and equal to $T_{1}$ during a condensation process. Since the cycle ECE is calculated for $1 \mathrm{~kg}$ of a working fluid, the heat supplied on line "6-1" is numerically equal to specific heat of a phase transition. Thus, the general expression for ECE of the Rankine cycle is determined using a formula [8]

$$
\eta_{R}=\left(\frac{p_{2}-p_{1}}{L\left(T_{1}\right)}\right) \cdot\left[\left(v_{5}-v_{1}\right)+0.5 \cdot\left(v_{6}-v_{5}\right)\right],
$$

where $p_{1}, p_{2}$ are freon pressures on lines "2-5" and "6-1" (Fig. 2), respectively, Pa; $L\left(T_{1}\right)-$ specific heat of "boiling-condensation" phase transition, $\mathrm{J} / \mathrm{kg} ; \mathrm{v}_{1}, \mathrm{v}_{5}, \mathrm{v}_{6}$ are specific volumes of freon at points "1", "5", "6" (Fig. 1), respectively, $\mathrm{m}^{3} / \mathrm{kg}$.

In order to perform calculations using the formula (2) values $v_{1}$ and $v_{6}$ (specific volumes in a state of saturation of liquid and steam phases, respectively) for a specific freon are determined by reference data $[15,16]$. Temperature of freon on line "2-4" in a process of heating and evaporating is constant and equal to $T_{2}$. Superheating of freon to a temperature $T_{5}$ on line "4-5" is necessary in order to avoid freon drops condensation on blades of a turbo machine. Freon pressure is known at point "5", which is equal to $p_{1}$. Thus, specific volume of freon $v_{5}$ and freon temperature $T_{5}$ at point "5" are unknown. However, a different variant of location of an isentrope "5-6" is possible. This variant is when the isentrope of steam expansion in a turbine starts at point "4", then points "4" and "5" coincide. In this case, the isentrope of expansion at point "6" goes into a region of superheated steam and freon parameters at point "5" (point "4") are known. The problem is about determining $\mathrm{v}_{6}$ and $p_{6}$ in this case.

Use a thermal equation of state (TES) of a working fluid [9-11] in order to determine thermodynamic ECE of freon usage in the Rankine cycle depending on thermodynamic properties of freon. Analysis results of known literary sources indicate that it is most rational for freons to use the empirical TES of Redlich-Kwong [12]:

$$
\begin{gathered}
p_{R K}(\mathrm{v}, T)=\frac{R_{g f} T}{v-b}-\frac{a}{\mathrm{v}(\mathrm{v}+b) \sqrt{T}}, \\
R_{g f}=\frac{R_{g u}}{M_{f}},
\end{gathered}
$$

where $R_{g u}=8.314 \mathrm{~J} /(\mathrm{kg} \cdot \mathrm{K})$, universal gas constant; $M_{f}$ is molecular mass of freon, $\mathrm{kg} / \mathrm{mol}$; $T$ is temperature, $\mathrm{K} ; \mathrm{v}$ is specific volume, $\mathrm{m}^{3} / \mathrm{kg} ; b$ is a constant of the Redlich-Kwong equation, which characterizes the forces of intermolecular repulsion, $\mathrm{m}^{3} / \mathrm{kg} ; a$ is a constant of the Redlich-Kwong equation, which characterizes the forces of intermolecular attraction, $\mathrm{Pa} \cdot \mathrm{m}^{6} \cdot \mathrm{K}^{0.5} / \mathrm{kg}^{2}$.

In order to estimate the ECE of a thermodynamic cycle, it is necessary to have thermodynamic parameters of a working fluid at some key points of the cycle, which are interconnected through lines of isentropic processes. In order to do this, it is necessary to establish the form of equation of an isentropic process for freon with TES of RedlichKwong. Thus, formulate the total differential of entropy in variables $v$ and $T$ in a general form 


$$
d S=\left(\frac{\partial S}{\partial v}\right)_{T} d v+\left(\frac{\partial S}{\partial T}\right)_{v} d T
$$

which after the usage of one of Maxwell's relations and thermodynamic determination of entropy [9]

$$
\left(\frac{\partial S}{\partial \mathrm{v}}\right)_{T}=\left(\frac{\partial p}{\partial T}\right)_{\mathrm{v}}, \quad\left(\frac{\partial S}{\partial \mathrm{v}}\right)_{T}=\frac{C_{\mathrm{v}}(\mathrm{v}, T)}{T}
$$

takes the following form

$$
d S=\left(\frac{\partial p}{\partial T}\right)_{v} d v+\frac{C_{\mathrm{v}}(\mathrm{v}, T)}{T} d T
$$

where $S$ is entropy, $\mathrm{J} /(\mathrm{kg} \cdot \mathrm{K}) ; C_{\mathrm{v}}(\mathrm{v}, \mathrm{T})$ is isochoric thermal capacity, $\mathrm{J} /(\mathrm{kg} \cdot \mathrm{K})$.

Considering the known thermodynamic identity [11]

$$
\left(\frac{\partial C_{\mathrm{v}}(\mathrm{v}, T)}{\partial \mathrm{v}}\right)_{T}=T\left(\frac{d^{2} p(\mathrm{v}, T)}{d^{2} T}\right)_{\mathrm{v}},
$$

determine the functional dependency of isochoric thermal capacity for the Redlich-Kwong equation

$$
\left(\frac{\partial C_{v}(v, T)}{\partial v}\right)_{T}=\frac{-3 a}{4 v(v+b) \sqrt{T^{3}}}
$$

By integrating the expression (9), the following is obtained

$$
C_{\mathrm{v}}(\mathrm{v}, T)=\frac{3 a}{4 b T^{1.5}} \ln \left(\frac{\mathrm{v}+b}{\mathrm{v}}\right)+C_{\mathrm{v}}^{0}(T),
$$

where $C_{\mathrm{v}}{ }^{0}(T)$ is a constant obtained during the integration of expression (8) with respect to $\mathrm{v}, \mathrm{J} /(\mathrm{kg} \cdot \mathrm{K})$.

Considering the fact that the studied freons are organic compounds, a second-degree polynomial is used to model the dependency of isochoric thermal capacity on temperature [13]

$$
C_{\mathrm{v}}^{0}(\mathrm{v}, T)=c+d T+k T^{2}
$$

where $c, d, k$ are constants, which correspond to freon class.

After determining the derivative $\left(\partial p_{R K} / \partial T\right)_{v}$ using the Redlich-Kwong equation (3) considering formulas (7) and (11), obtain that the full differential of entropy for a RedlichKwong fluid gets the form

$$
d S_{R K}(\mathrm{v}, T)=\left[\frac{R_{g f}}{\mathrm{v}-b}+\frac{a}{2 \mathrm{v}(\mathrm{v}+b) T^{1.5}}\right] d v+\left[\frac{3 a}{4 b T^{2.5}} \ln \left(\frac{\mathrm{v}+b}{\mathrm{v}}\right)+\frac{C_{\mathrm{v}}^{0}(T)}{T}\right] d T,
$$

The right part of (12) represents the full differential of a function, which depends on variables $v$ and $T$, since the second mixed derivatives of a function are equal to each other. 
When determining the function $S_{R K}(v, T)$ during the integration of (11) it must be considered that the multiplier function of the differential $d v$ depends on $T$, and the multiplier function of the differential $d T$ depends on $v$, then by determining partial derivatives of the first order of the function

$$
\begin{gathered}
S_{R K}(\mathrm{v}, T)=A_{S}(\mathrm{v}, T)-A_{S}\left(\mathrm{v}_{0}, T_{0}\right), \\
A_{S}(\mathrm{v}, T)=R_{g f} \ln (\mathrm{v}-b)+\frac{a}{2 b T^{1.5}} \ln \left(\frac{\mathrm{v}}{\mathrm{v}+b}\right)+c \ln (T)+d T+\frac{k T^{2}}{2},
\end{gathered}
$$

it is ensured that the function (13) is a full differential of expression (12). Thus, the function $S_{R K}(v, T)$ represents the expression for entropy of a substance, thermal properties of which are described by the Redlich-Kwong equation.

The method is developed for determining freon specific volume $v_{5}$ at point "5" and freon temperature $T_{5}$. These parameters are necessary for calculation of ECE (2) with a subsequent design process of equipment. Line "5-6" is adiabatic in Figure 2. Considering the neglect of processes of friction, formulate the isentrope as a non-linear equation with respect to $\mathrm{v}_{5}$ and $T_{5}$ based on the obtained expression for $S_{R K}(v, T)$

$$
A_{S}\left(\mathrm{v}_{5}, T_{5}\right)=A_{S}\left(\mathrm{v}_{6}, T_{1}\right)
$$

In order to exclude $T_{5}$ from equation (15), determine temperature for point "5" using the Redlich-Kwong equation at freon pressure $p_{1}$. The Redlich-Kwong equation with respect to $\left(T_{5}\right)^{1 / 2}$ represents a cubic equation

$$
\begin{gathered}
x^{3}-\theta x-1=0, \\
X=\left(\frac{\mathrm{v}_{5} R_{g f}}{a}\right)^{\frac{1}{3}}\left(\frac{\mathrm{v}_{5}+b}{\mathrm{v}_{5}-b}\right)^{\frac{1}{3}} \sqrt{T_{5}}, \quad \theta=\frac{p_{5}}{R_{g f}^{\frac{1}{3}}}\left(\frac{\mathrm{v}_{5}}{a}\right)^{\frac{2}{3}}\left(\mathrm{v}_{5}+b\right)^{\frac{2}{3}}\left(\mathrm{v}_{5}-b\right)^{\frac{1}{3}},
\end{gathered}
$$

the solution of which can be formulated as [14]

$$
\begin{gathered}
T_{5}=\left\{\begin{array}{l}
\left(\frac{a}{2 \mathrm{v}_{5} R_{g f}}\right)^{\frac{2}{3}}\left(\frac{\mathrm{v}_{5}-b}{\mathrm{v}_{5}+b}\right)^{\frac{2}{3}} \Omega_{1}^{2}, \quad \sqrt[3]{\sigma} \leq 1 \\
\frac{4 p_{5}\left(\mathrm{v}_{5}-b\right)}{3 R_{g f}} \Omega_{2}^{2},
\end{array}\right. \\
\Omega_{1}=\sqrt[3]{1+\sqrt{1-\sigma}}+\sqrt[3]{1-\sqrt{1-\sigma}}, \quad \Omega_{2}=\cos \left[\frac{1}{3} \arccos \frac{1}{\sqrt{\sigma}}\right]
\end{gathered}
$$

After substitution of (18) into (15) and considering (14), the equation for determining freon specific volume $v_{5}$ at point " 5 " for $\sigma \leq 1$ gets a form 


$$
\begin{aligned}
& W_{3} \ln \left(v_{5}-b\right)-W_{2} \ln \left(v_{5}+b\right)-W_{1} \ln v_{5}+W_{0}=A_{S}\left(v_{6}, T_{1}\right),
\end{aligned}
$$

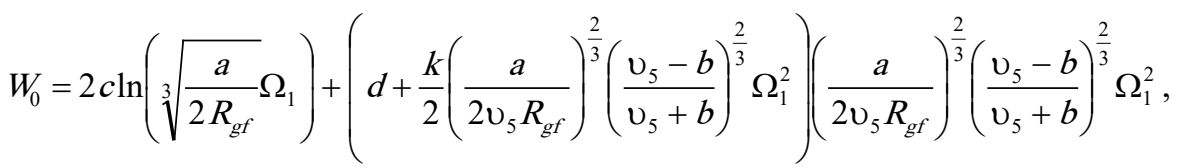

$$
\begin{aligned}
& W_{1}=\frac{2 c}{3}-\frac{\mathrm{v}_{5} R_{g f}\left(\mathrm{v}_{5}+b\right)}{b\left(\mathrm{v}_{5}-b\right) \Omega_{1}^{3}}, W_{2}=\frac{2 c}{3}+\frac{\mathrm{v}_{5} R_{g f}\left(\mathrm{v}_{5}+b\right)}{b\left(\mathrm{v}_{5}-b\right) \Omega_{1}^{3}}, W_{3}=R_{g f}+\frac{2 c}{3},
\end{aligned}
$$

for $\sigma>1$

$$
\begin{gathered}
W_{2} \ln \left(\mathrm{v}_{5}-b\right)+W_{1} \ln \left(\frac{\mathrm{v}_{5}}{\mathrm{v}_{5}+b}\right)+W_{0}=A_{S}\left(\mathrm{v}_{6}, T_{1}\right), \\
W_{0}=c \ln \left(\frac{4 p_{5}}{3 R_{g f}} \Omega_{2}^{2}\right)+\left[d+k \frac{2 p_{5}\left(\mathrm{v}_{5}-b\right)}{3 R_{g f}} \Omega_{2}^{2}\right] \frac{4 p_{5}\left(\mathrm{v}_{5}-b\right)}{3 R_{g f}} \Omega_{2}^{2}, \\
W_{1}=\frac{a}{16 b \Omega_{2}^{3}}\left(\frac{3 R_{g f}}{p_{5}\left(\mathrm{v}_{5}-b\right)}\right)^{\frac{3}{2}}, \quad W_{2}=R_{g f}+c .
\end{gathered}
$$

Thus, in order to determine $v_{5}$, a complex non-linear algebraic equation (20) or an equation (23) is obtained, depending on a value of $\sigma$. Newton's method can be used successfully and efficiently to solve the specified algebraic equation. Temperature $T_{5}$ can be calculated by solving an equation (20) or (23), after a substitution of $v_{5}$ into the right part of (18).

In order to solve non-linear algebraic equations (20) or (23), it is necessary to determine the range where a discriminant of equation (16) has a fixed sign, which is reduced to solving the following inequality

$$
\begin{gathered}
A(y) \leq \frac{27 a^{2} R_{g f}}{4 b^{5} p_{5}^{3}}, \\
A(y)=y^{2}(y+1)^{2}(y-1), \quad y=\frac{v_{5}}{b} .
\end{gathered}
$$

The results of a numerical analysis of dependency (27) for characteristic intervals $0.012 \leq \mathrm{v}_{5} \leq 0.082$ and $0.0049 \leq b \leq 0.00062$ [15] indicate that the considered dependency (Fig. 3) is approximated by a power dependency with high accuracy $\left(R^{2}=0.9999\right)$

$$
A=1.11 y^{5}
$$

which allows splitting the ranges of positive and negative discriminant of equation (16) by an inequality

$$
\mathrm{v}_{5} \leq \mathrm{v}_{k p},
$$




$$
\mathrm{v}_{k p}=1.435\left(\frac{a^{2} R_{g f}}{p_{5}^{3}}\right)^{\frac{1}{5}} .
$$

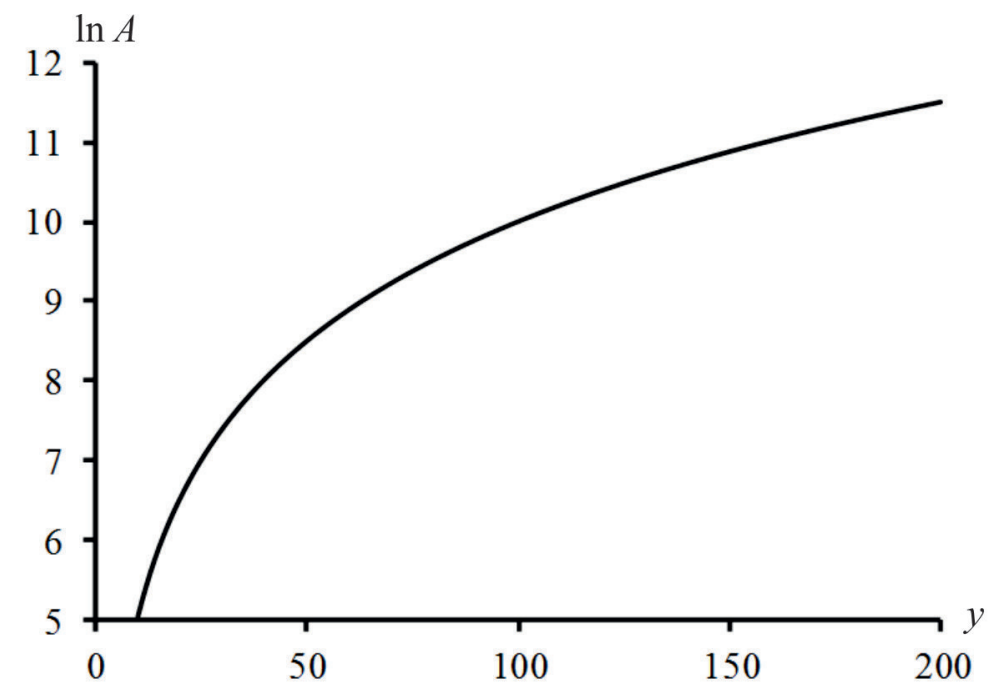

Fig. 3. Dependency of parameter $A$ on relative specific volume.

The value of $v_{5}$ for a considered working fluid is determined using formulas (20) - (22) if inequality (28) is fulfilled, otherwise - by using expressions (23) - (25).

\section{Results and discussion}

It is characteristic for a freon as a working fluid to have thermal stability in a range of operating temperatures and it must also fulfill the requirements of ecologic indicators. The experience of usage of alkanes like pentane as a working fluid in systems of utilization of carbohydrate energy is known. However, it is obvious that the consideration of fire and explosion safety must play no less of an important role in working fluid selection than the estimation of thermal efficiency of a corresponding thermodynamic cycle with the usage of any substance. Based on the above, the suggested principles of selection of working fluids for systems are about the following. The substances with $O D P=0$ are initially included in the selection. Freons with smaller indicators of toxicity and flammability should be considered first from a series of ozone-safe freons. Thermodynamic efficiency of usage of the selected freon in a specific thermodynamic cycle is estimated further. By considering the minimum flammability principle, the focus should be put on the freons, the molecules of which contain the least hydrogen atoms or hydrogen is absent entirely. Freons R-134a, R-125, R-32, R-227ea, R-227ca are recommended as such based on the suggested principles of selection of working fluids for systems of utilization of low-potential heat. Molecules of these freons contain only one hydrogen atom each. Freons R-236fa and R-236ea should be especially considered, they contain two hydrogen atoms each. Analyze the prospects of application of freons R-125 and R-236ea based on the principles of selection of working fluids.

The calculations for freons R-125 and R-236ea are performed by the method considered above. Their thermodynamic parameters are presented in Table $1[15,16]$.

The data on thermodynamic parameters of R-125 and R-236ea at calculation points of the Rankine cycle (Fig. 2) with a freon-steam turbine are obtained by using the method above 
and are presented in Table 2 .

The feature of the results presented in Table 2 is about that the freon R-125 steam is superheated at point "5", and freon R-236ea steam is in superheated state at point "6". Freon superheating at points " 5 " or " 6 " is maintained by thermodynamic properties of the selected working fluid and is connected with a necessity of closing the freon circulation contour into a thermodynamic cycle.

Table 1. Constants of the Redlich-Kwong equation and isochoric thermal capacity for freons $\mathrm{R}-125$ and R-236ea $[15,16]$.

\begin{tabular}{|l|c|c|}
\hline \multirow{2}{*}{$\begin{array}{c}\text { Parameter, } \\
\text { unit }\end{array}$} & \multicolumn{2}{|c|}{ Freon class } \\
\cline { 2 - 3 } & $\mathrm{R}-125$ & $\mathrm{R}-236 \mathrm{ea}$ \\
\hline$a,\left(\mathrm{Nm}^{4} \cdot \mathrm{K}^{1 / 2}\right) / \mathrm{kg}^{2}$ & 1212 & 1290 \\
\hline$b, \mathrm{~m}^{3} / \mathrm{kg}$ & $6.057 \cdot 10^{-4}$ & $5.742 \cdot 10^{-4}$ \\
\hline$c, \mathrm{~J} / \mathrm{kg} \cdot \mathrm{K})$ & 213.52 & 225.4 \\
\hline$\left.d, \mathrm{~J} / \mathrm{kg} \cdot \mathrm{K}^{2}\right)$ & 1.59 & 1.76 \\
\hline$k, \mathrm{~J} /\left(\mathrm{kg} \cdot \mathrm{K}^{3}\right)$ & $-5.8 \cdot 10^{-4}$ & 0 \\
\hline
\end{tabular}

Table 2. Parameters of freons R-125 and R-236ea at calculation point of the Rankine cycle

\begin{tabular}{|l|c|c|c|c|c|c|}
\hline \multirow{2}{*}{$\begin{array}{c}\text { Number of point, working } \\
\text { fluid state }\end{array}$} & \multicolumn{2}{|c|}{$\begin{array}{c}\text { Pressure, } \\
\mathrm{MPa}\end{array}$} & \multicolumn{2}{c|}{$\begin{array}{c}\text { Specific volume, } \\
\mathrm{m}^{3} / \mathrm{kg}\end{array}$} & \multicolumn{2}{c|}{$\begin{array}{c}\text { Temperature, } \\
{ }^{\circ} \mathrm{C}\end{array}$} \\
\cline { 2 - 8 } & $\mathrm{R}-125$ & $\mathrm{R}-236 \mathrm{ea}$ & $\mathrm{R}-125$ & $\mathrm{R}-236 \mathrm{ea}$ & $\mathrm{R}-125$ & $\mathrm{R}-236 \mathrm{ea}$ \\
\hline $\begin{array}{l}\text { 1, saturated freon after } \\
\text { condenser }\end{array}$ & 1.205 & 0.171 & 0.00082 & 0.00073 & 20.0 & 20.0 \\
\hline 2, non-boiling freon & 2.539 & 0.453 & 0.00082 & 0.00073 & 50.0 & 50.0 \\
\hline 3, boiling freon & 2.539 & 0.453 & 0.00099 & 0.00074 & 50.0 & 50.0 \\
\hline $\begin{array}{l}\text { 4, dry saturated freon } \\
\text { steam }\end{array}$ & 2.539 & 0.453 & 0.00559 & 0.03440 & 50.0 & 50.0 \\
\hline $\begin{array}{l}\text { 5, superheated steam or } \\
\text { dry saturated steam }\end{array}$ & 2.539 & 0.453 & 0.00586 & 0.03440 & 50.0 & 53.8 \\
\hline $\begin{array}{l}\text { 6, dry saturated freon } \\
\text { steam }\end{array}$ & 1.205 & 0.12 & 0.01364 & 0.09190 & 20.0 & 27.4 \\
\hline
\end{tabular}

Consider the energy efficiency of usage of selected freons as working fluids for systems of energy utilization of low-potential sources. The calculations by expression (2) based on the data of Table 2 indicated that the Rankine cycle ECE with freon R-125 as a working fluid is $10.7 \%$, and with freon R-236ea is $11.1 \%$. It should be noted that freon R-125 on line "4-5" must be superheated to a temperature of $53.8^{\circ} \mathrm{C}$ to avoid freon drops condensation at point "6", and freon R-236ea, for which parameters at points "4" and "5" coincide, is supplied to point "6" already superheated to a temperature of $27.4{ }^{\circ} \mathrm{C}$. Considering that the Rankine cycle ECEs are almost equal when using the considered freons, the further selection of freon usage efficiency is performed based on the analysis of parameters of corresponding equipment. This equipment is steam super heater for freon $\mathrm{R}-125$ with a temperature of up to $53.8^{\circ} \mathrm{C}$ before a freon-steam turbo machine. For freon $\mathrm{R}-236 \mathrm{ea}$ it is an additional steam cooler from $27.4{ }^{\circ} \mathrm{C}$ to $20^{\circ} \mathrm{C}$ before a condenser. ECE values obtained for the two selected freons are sufficiently high considering that the volumes of WER, which are viable for useful generation of electric energy, greatly increase when the operating temperature is reduced. As known [8], ECE increases more efficiently 
when "cooler" temperature decreases, thus, further ECE increase of energy utilization systems of low-potential sources can be achieved by researching a possibility of using cold water from rivers and reservoirs as a freon cooler in a condenser.

\section{Conclusion}

1. A calculation method of thermodynamic parameters that are necessary for ECE estimation of specific freons in a system of useful utilization of energy is developed. The method is based on solving the Redlich-Kwong equation with respect to temperature and by solving one non-linear equation using Newton's method.

2. Principles of selection of freons for systems of thermal energy utilization of lowpotential sources are developed. Freons R-134a, R-125, R-227ea, R-227ca, R-32, R-236fa, $\mathrm{R}-236 \mathrm{ea}$ are suggested for systems as working fluids based on these principles. The list of freons can not be considered finalized considering the modern additional requirements for regulation of rates of global warming.

3. Thermodynamic analysis of prospects of usage of suggested freons in systems of thermal energy utilization of low-potential sources with a freon-steam turbine indicated their high efficiency. Thus, the usage of energy equipment with a freon-steam turbine and the usage of freon R-125 or R-236ea in MEC allows additional utilization of thermal energy of sources with the lowest level of temperature potential and improve economic efficiency of complex operation.

\section{References}

1. Bulat, A.F., Chemeris, I.F. (2006). Nauchno-tekhnicheskie osnovy sozdaniia shakhtnykh kogeneratsionnykh energeticheskikh kompleksov. Kyiv: Naukova dumka

2. Gichev, Yu.P. (2012). Vtorichnye energoresursy promyshlennykh predpriiatiy. Dnepropetrovsk: NMetAU

3. Morozov, Yu.P. (2017). Dobycha geotermalnykh resursov $i$ akkumulirovaniye teploty $v$ podzemnykh gorizontakh. Kyiv: Naukova Dumka

4. Shurchkova, Yu.A. (2018). World trends in the development of geothermal energy. Part 1 Geothermal resources by region of the world. Problemy obshchey energetiki, 4, 17-24

5. Zysin, V.A. (1962). Kombinirovannye parogazovye ustanovki $i$ tsikly. Moskva Leningrad: Gosenergoizdat

6. Tsvetkov, O.B., Laptev, Yu.A. (2002). Thermophysical aspects of environmental problems of modern refrigeration equipment. Khimiia i kompyuternoe modelirovanie. Butlerovskie soobshcheniia, 10, 54-57

7. Yanchoshek, L., Kunts, P. (2012). Organic Rankine Cycle: Use in Cogeneration. Turbiny $i$ dizeli, 2, 50-53

8. Andryushchenko, A.I. (1985). Osnovy termodinamiki tsiklov teploenergeticheskikh ustanovok. Moskva: Vysshaya shkola

9. Mayyer, Dzh., Geppert-Mayyer, M. (1980). Statisticheskaya mekhanika. Moskva: Mir

10. Bogolyubov, N.N. (1970). Izbrannyye trudy. Kyiv: Naukova Dumka

11. Landau, L.D., Lifshits, Ye.M. (1976). Statisticheskaia fizika. Moskva: Nauka

12. Rid, R., Prausnnits, Dzh., Shervud, T. (1982). Svoystva gazov i zhidkostey. Leningrad: Khimiya

13. Ravdel, A.A., Ponomarov, A.M. (1983). Kratkiy spravochnik fiziko-khimicheskikh velichin. Leningrad: Khimiya

14. Korn, G., Korn, T. (1970). Spravochnik po matematike dlya nauchnykh rabotnikov $i$ inzhenerov. Moskva: Nauka 
15. Bogdanov, S.N., Burtsev, S.I., Ivanov, O.P., Kupriyanova, A.V. (1999). Kholodilnaia tekhnika i konditsionirovaniye vozdukha. Svoystva veshchestv. SPb.: SPbGAKHPT

16. Komarov, S.G. Gruzdev, V.A., Stankus, S.V. (2008). Sound speed and ideal gas heat capacity of R-236ea Freon. Teplofizika i aeromekhanika, 15, 3, 395-397 